\title{
Potamonautid river crabs (Decapoda, Brachyura, Potamonautidae) of KwaZulu-Natal, South Africa
}

\author{
G Gouws* and BA Stewart \\ Department of Zoology, University of Stellenbosch, Private Bag X1, Matieland 7602, South Africa
}

\begin{abstract}
The recent descriptions of Potamonautes dentatus, P. clarus and P. lividus have brought the number of species recorded from KwaZulu-Natal (South Africa) to five, with $P$. depressus depressus and $P$. sidneyi having long been known from the province. To determine and quantify levels of genetic differentiation between these species, 14 populations were analysed using allozyme electrophoresis of 14 presumptive loci. Interspecific genetic identity-values ranged between 0.224 and 0.793 ( $D=0.233$ to 1.495 ), with between one and ten fixed allele differences present among species. Morphometric differentiation between species was examined using discriminant function analyses of seven carapace and eight pereiopod variables. Species were found to be well defined along the first two canonical variables, in terms of carapace and pereiopod morphometrics. Results are discussed in light of genetic and morphometric differentiation documented for the genus. The distribution of each species was determined, using data from 220 collection localities, plotted, and discussed. A key for the identification of the species occurring in the province is provided.
\end{abstract}

\section{Introduction}

River crabs are the largest invertebrates and constitute the largest biomass in many of South Africa's rivers (Hill and O'Keeffe, 1992). They are important prey items, forming the dominant component of the diet of the otter and water mongoose (Purves et al., 1991), many bird species (Arkell, 1979), and fish species. The crabs are, themselves, important detritivores; reducing the particle size of leaf litter and organic debris, presenting a source of nutrition to collector and filter-feeding river fauna, and enabling microbial activity (Hill and O'Keeffe, 1992). These crabs utilise energy from diverse trophic levels and contribute to energy and resource recycling within the river ecosystem (Hill and O'Keeffe, 1992).

Elsewhere in Africa, they are valued as a food source (Sachs and Cumberlidge, 1991; Cumberlidge and Clark, 1992). Freshwater crabs are also known to be vectors of parasitic disease, as the intermediate hosts of the fluke-worms, Paragonimus uterobilateralis and $P$. africanus, which cause paragonimiasis in humans (Cumberlidge, 1989; Sachs and Cumberlidge, 1991). Recently, work has been done investigating the use of crabs as indicators of aquatic pollution, particularly through heavy metals (Steenkamp et al., 1993; 1994).

Despite their importance in the river ecosystem, the group has not been researched thoroughly. Since the cataloguing work of Barnard (1935; 1950), Bott (1955) and, more recently, the revision by Kensley (1981), the freshwater crab fauna of South Africa has received little attention. These authors had documented five species of freshwater river crab from South Africa, all belonging to the family Potamonautidae.

In particular, the taxonomy and systematics of the group have remained obscure, largely due to the fact that classifications have been based on sparse and poor sampling, without an adequate understanding of the variation which is evident within the group. Furthermore, taxa have been defined, often arbitrarily, with the

*To whom all correspondence should be addressed.

㿿(021) 808-3229; fax (021) 808-2405; e-mail: ggouws@akad.sun.ac.za Received 25 July 1999; accepted in revised form 18 August 2000 apparent presence of intergrading, transitional forms being problematic (Rathbun, 1921; Barnard, 1935; 1950). Often distinctions were made based on the possession of extreme features, which could have been revealed as a series, with sufficient sampling localities and individuals (Barnard, 1935). A project was thus launched in 1992 to resolve the taxonomy of the group, by means of intensive collecting, and genetic and morphological analyses. Since its inception, four new species have been described from regions outside of KwaZulu-Natal (Stewart, 1997a; b; Stewart and Cook, 1998; Daniels et al., 1998a).

From the existing literature it is apparent that Potamonautes sidneyi, and Potamonautes depressus depressus have long been known to occur within KwaZulu-Natal (Krauss, 1843; Stebbing, 1910; Lenz-Lübeck, 1912; Barnard, 1935; 1950; Dandy and Ewer, 1961; Kensley, 1981). However, a number of other species have also been recorded from the province. Rathbun (1906) catalogued collections made at Port Natal (Durban), which included the type specimen of Potamonautes inflatus. This species was later synonymised with $P$. depressus depressus by Bott (1955), and subsequently confirmed by examination of the type specimen.

A single specimen of $P$. bayonianus dubius var. jallae was collected at Howick Falls, near Pietermaritzburg and documented by Balss (1922). Barnard (1935), however, believed the specimen to be an outlier of $P$. warreni (a species believed to be restricted to the Orange River system), as the specimen showed reduced teeth on the anterolateral margin and resembled specimens of $P$. warreni collected from the former Transvaal. Balss (1936), however, defended his identification.

Dandy and Ewer (1961) listed P. warreni as occurring in KwaZulu-Natal, stating that, as the species had never been recorded from the region before, it was probably an invader from the Orange River. Colosi (1924) had earlier documented collections of $P$. warreni made at Port Natal. Barnard (1950) suggests that, as the collector (Wahlberg) had travelled to the Transvaal, there is reason to believe that the specimens were collected much further north. It is, however, probable that the P. bayonianus dubius specimen and the $P$. warreni specimens are specimens of $P$. dentatus, a species (also characterised by the possession of dentate anterolateral 


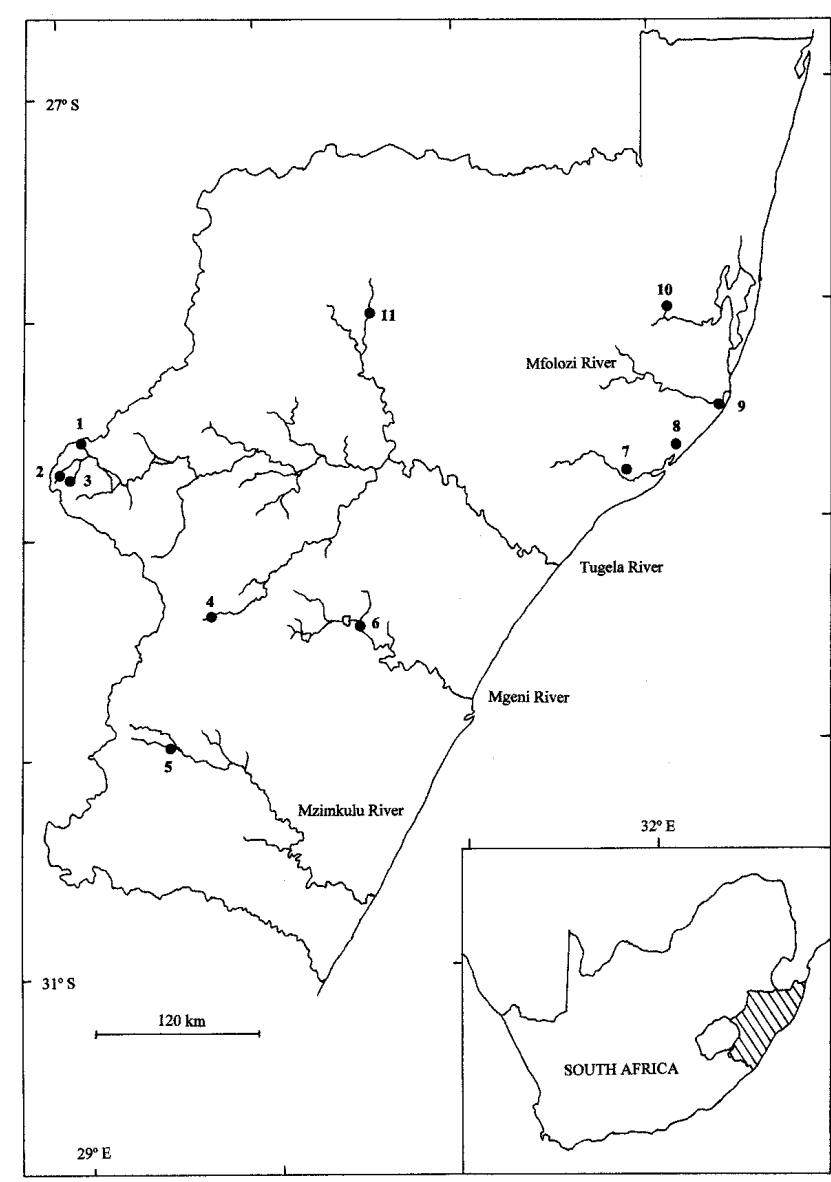

Figure 1

Sampling localities of the Potamonautes populations studied: Oliviershoek (1), Mahai (2), Tendele (3), Kamberg (4), Coleford (5), Mgeni (6), University of Zululand (7), Mdibi (8), Mapelane (9), Hluhluwe (10), and the Blood River (11). Consult the text for further details

carapace margins) described from KwaZulu-Natal by Stewart et al. (1995). Stebbing (1910: 295) mentions "another variety" of Potamonautes occurring at Port Natal, possibly in reference to $P$. depressus depressus, or $P$. dentatus.

Both Colosi (1924) and Barnard (1935; 1950) have questioned the validity of recognising $P$. perlatus (Cape river crab) and $P$. sidneyi (Natal river crab) as being separate species, because a complete morphological transition exists between the two. This has led to inconsistencies in the identification of specimens in the past (e.g. Lenz-Lübeck, 1912). As a result, $P$. sidneyi has been recorded as occurring as far westwards as the Western Cape (Barnard, 1950), and P. perlatus has been documented as occurring in KwaZulu-Natal (Krauss, 1843; Hilgendorf, 1898; Rathbun, 1906: 372). However, Potamonautes sidneyi was only catalogued (1904: 241) and figured (1904: Plate 14, Fig. 5) by Rathbun in 1904 , and described in 1905 (Rathbun, 1905). The misidentifications, thus, bear testimony to the similarity of the two species. The validity of these two species is currently being investigated using genetic data.

Recently, Potamonautes dentatus was described from collections made along the Mgeni River and was delineated from $P$. warreni, using morphological and morphometric evidence (Stewart et al., 1995). This species can be readily distinguished from other species from the province, by the possession of a series of teeth on the anterolateral carapace margin, and can be distinguished from dentate species occurring further afield by the presence of a notch in the post-frontal crest, posterior to the exorbital teeth (Stewart et al., 1995).

Potamonautes clarus, once regarded as $P$. depressus depressus in museum collections, was recently distinguished from the latter species on the basis of genetic, morphological and colour differences (Gouws et al., 2000). Allozyme electrophoresis revealed the two species to be the most disparate of all Potamonautes species yet compared, with five diagnostic loci distinguishing the two species (Gouws et al., 2000).

Potamonautes lividus was described from patches of Syzygium cordatum, Barringtonia racemosa and Ficus trichopoda-dominated swamp forest from north-eastern KwaZulu-Natal (Gouws et al., 2001). The species was delineated on the basis of morphometric, morphological, and genetic evidence, with allozyme electrophoresis showing the species to be reproductively isolated from sympatric populations of $P$. sidneyi (Gouws et al., 2001).

This paper explores the levels of genetic and morphological differentiation between the species known to occur in KwaZuluNatal, using data from selected populations of each species. The differentiation within Potamonautes is discussed against the broader evidence of differentiation within the genus and a key for the identification of the species of the province is provided. The distributions of the species in KwaZulu-Natal are dicussed and mapped.

\section{Materials and methods}

\section{Collections}

In order to determine species' distributions, collection data were recorded from 220 localities. Collections housed at the South African Museum, Transvaal Museum and Albany Museum, as well as collections made by KwaZulu-Natal Nature Conservation Services staff and biologists from other institutions, were examined. Collections for genetic analyses were made using handnets baited with ox-heart during extensive field trips to the province. Crabs were identified and sexed, with parameters recorded in a comprehensive database. Individuals were either preserved as vouchers, or frozen and dissected for genetic analyses.

In order to determine levels of interspecific genetic and morphological differentiation, 14 populations, representing all five species from the province were chosen. Where possible, populations occurring sympatrically with other species were used. Sampling localities are illustrated in Fig. 1.

Populations of Potamonautes clarus were sampled from:

- Oliviershoek Pass

- Mahai stream (Royal Natal National Park)

- The Tugela River, below the Tendele Rest Camp (Royal Natal National Park).

Populations of $P$. depressus depressus were sampled from:

- Kamberg Nature Reserve

- Coleford Nature Reserve.

Samples of $P$. lividus were collected from:

- The University of Zululand campus

- Mdibi swamp forest, near Richards Bay

- Mapelane Nature Reserve. 


\begin{tabular}{|c|c|c|c|c|}
\hline \multicolumn{5}{|c|}{$\begin{array}{c}\text { TABLE 1 } \\
\text { Enzyme and buffer systems utilised in the genetic analyses } \\
\text { Buffer: (A) discontinuous Tris-citrate-borate-lithium hydroxide buffer system } \\
\text { (Ridgeway et al., 1970), (B) continuous Tris-borate-EDTA buffer system (Markert and } \\
\text { Faulhaber, 1965), and (C) continuous Tris-citrate buffer system (Whitt, 1970) }\end{array}$} \\
\hline Enzyme & Abbreviation & E.C. Number & Buffer & Loci \\
\hline $\begin{array}{l}\text { Arginine kinase } \\
\text { Glucose-6-phosphate isomerase } \\
\text { Hexokinase } \\
\text { Isocitrate dehydrogenase } \\
\text { Lactate dehydrogenase } \\
\text { Malate dehydrogenase } \\
\text { Malic enzyme } \\
\text { Mannose-phosphate isomerase } \\
\text { Peptidase (glycyl-leucine as substrate) } \\
\text { Peptidase (leucyl-tyrosine as substrate) } \\
\text { Phosphoglucomutase }\end{array}$ & $\begin{array}{l}\text { ARK } \\
\text { GPI } \\
\text { HEX } \\
\text { IDH } \\
\text { LDH } \\
\text { MDH } \\
\text { ME } \\
\text { MPI } \\
\text { PEP-GL } \\
\text { PEP-LT } \\
\text { PGM }\end{array}$ & $\begin{array}{l}2.7 .3 .3 . \\
5.3 .1 .9 . \\
2.7 .1 .1 . \\
1.1 .1 .42 . \\
1.1 .1 .27 . \\
1.1 .1 .37 \\
1.1 .1 .40 \\
5.3 .1 .8 \\
3.4 .11 .- \\
3.4 .11 .- \\
5.4 .2 .2 .\end{array}$ & $\begin{array}{l}\text { A } \\
\text { A } \\
\text { B } \\
\text { C } \\
\text { A } \\
\text { C } \\
\text { B } \\
\text { B } \\
\text { B } \\
\text { A } \\
\text { B }\end{array}$ & $\begin{array}{l}1 \\
1 \\
1 \\
2 \\
1 \\
2 \\
1 \\
1 \\
1 \\
2 \\
1\end{array}$ \\
\hline
\end{tabular}

Five populations of $P$. sidneyi were included, collected from:

- The University of Zululand campus

- The Manzibomvu River in the Hluhluwe Game Reserve

- The Blood River, in the northern midlands

- The Oliviershoek (B) Pass

- The Mahai (B) stream.

A single population of $P$. dentatus from the Mgeni River was included.

\section{Genetic analyses}

Interspecific genetic differentiation was examined using allozyme electrophoresis, a technique that has its strongest application in the delimitation of taxonomic groups (Stevens, 1991; Thorpe and Solé-Cava, 1994), particularly at the lower taxonomic levels (Mabee and Humphries, 1993). Electrophoresis has been successfully applied in the resolution of the systematic relationships of the potamonautid crabs in South Africa (Stewart, 1997a; b; Stewart and Cook, 1998; Daniels et al., 1999).

Muscle tissue was removed from each specimen and stored at $-80^{\circ} \mathrm{C}$, until electrophoresis could be performed. Tissue was subsequently homogenised in $0.01 \mathrm{M}$ Tris buffer ( $\mathrm{pH} 8$ ), using a glass rod attached to a variable-speed electric motor. Samples were centrifuged for $5 \mathrm{~min}$ at $12000 \mathrm{r} \cdot \mathrm{min}^{-1}$ prior to use. Filter paper wicks (Whatmans \#3) were dipped into the supernatant and inserted into the horizontal $13 \%$ starch gel.

Three electrophoretic buffer systems were used for running the gels (Table 1): (A) a discontinuous Tris-citrate-borate-lithium hydroxide buffer; with a gel buffer $\mathrm{pH} 8.7$, and an electrode buffer pH 8.0 (Ridgeway et al., 1970); (B) a continuous Tris-borateEDTA buffer system, at pH 8.6 (Markert and Faulhaber, 1965); and (C) a continuous Tris-citrate buffer system, at pH6.9 (Whitt, 1970). The gels were run, inside a fridge $\left(4^{\circ} \mathrm{C}\right)$, for $4 \mathrm{~h}$ at $40 \mathrm{~mA}$, then removed and sliced horizontally into 4 slices. Sites of enzymatic activity were histochemically stained in a $2 \%$ agar overlay (Shaw and Prasad, 1970).

Of 24 isozyme loci originally screened, 14 were reliably interpretable, and could be extrapolated across all populations (Table 1). The Coleford population was included in each run as a reference point, to provide continuity in scoring across all populations. For each locus, the most common allele of the Coleford population was assigned a value of 100 and all other alleles were scored relative to this value. Where more than one locus stained for a particular enzyme, the most anodally migrating one was labelled 1 , the others being labelled sequentially.

Numerical analyses of genetic data were performed using the BIOSYS-1 program (Swofford and Selander, 1981). Allele and genotype frequencies were calculated. Genotype frequencies were tested for deviation from those frequencies expected under HardyWeinberg equilibrium by means of a $\chi^{2}$-goodness-of-fit test. Where more than two alleles occurred at a locus, the genotype frequencies of heterozygous combinations and rare homozygous combinations were pooled, in turn. Levene's (1949) correction for small sample sizes was employed in these calculations. Percentage polymorphic loci were calculated for each population, using no criterion (loci were considered polymorphic if more than one allele was present at a locus), and a 0.95 criterion (loci are considered polymorphic if the frequency of the most abundant allele does not exceed 0.95). The mean expected heterozygosity was also calculated for each locus, using unbiased estimates (Nei, 1978). The mean unbiased (Nei, 1978) genetic identity $(I)$ and distance $(D)$ were calculated for each pair-wise comparison of populations and a dendrogram was constructed using the measures of genetic identity and the UPGMA clustering algorithm (Sneath and Sokal, 1973). Further, Wright's (1978) F-statitics $\left(\mathrm{F}_{\mathrm{ST}}\right)$ were calculated for each locus, in turn, and all loci combined. These statistics reflect the proportion of genetic variability that is attributable to differentiation among populations (rather than differentiation between individuals) across the entire sample.

\section{Morphometric analyses}

Discriminant function analysis was the principle methodology followed, a technique finding increasing application in systematics (Sokal and Rohlf, 1981; Thorpe, 1988). Discriminant function analyses are used to ordinate groups and have proved useful in the study of geographic variation (Thorpe, 1976). Discriminant function analysis of carapace variables has proved successful in resolving the systematic relationships of the group and revealing patterns of geographic differentiation (Stewart, 1997a; b; Stewart and Cook, 1998; Daniels et al., 1998a; b). 
Crabs were measured using digital Vernier-calipers. Populations used in the genetic analyses were supplemented with morphometric data from specimens collected earlier at the same localities. No morphometric data were recorded for the Oliviershoek (B) $P$. sidneyi population, which was omitted from the analyses. Seven carapace and eight pereiopod variables were recorded. These were:

- The carapace length, along the medial line (CL)

- The carapace width at its widest point (CWW)

- The posterior carapace width (CWP)

- The distance between the post-frontal crest and the anterior carapace margin (PFCD)

- The distance between the medial margins of the orbits (ED)

- The distance between the exorbital teeth (CWA)

- The carapace height $(\mathrm{CH})$

- The length (P2PL) and width (P2PW) of the propodus of the second pereiopod

- The length (P2ML) and width (P2MW) of the merus of the second pereiopod

- The length and width of the propodus of the 5th pereiopod (P5PL and P5PW)

- The length and width of the merus of the 5th pereiopod (P5ML and P5MW).

Data were log-transformed (common logarithms) prior to analysis. All statistical analyses were performed using the Statistica Version 5.1 program (StatSoft Inc., 1996). Morphometric variation between the species was determined by means of stepwise discriminant function analyses of the seven carapace variables and eight pereiopod variables, in turn. Classification functions (linear combinations of variables which best describe each group) were calculated, using a jack-knife procedure, ensuring an unbiased classification function for determining group assignment. Individuals were then reassigned to a group, using classification functions, based on highest $a$ posteriori probabilities. Individuals were plotted two-dimensionally based on canonical (discriminant) Variable 1 and canonical Variable 2 scores, to determine the extent of differentiation.

\section{Results}

\section{Genetic analyses}

Of the 14 loci included in the analysis, one (LDH) was monomorphic, leaving 13 polymorphic loci. Three loci (ARK, ME, MPI) were monomorphic in all individual populations, but polymorphic across populations. Allele frequencies at the polymorphic loci are presented in Table 2. The number of alleles per polymorphic locus ranged from two, in ARK, PEP-LT-1, ME, MDH-1 and MPI, to six, in GPI. The highest number of alleles occurring at a specific locus in a single population was four, at the PEP-GL locus in the Coleford population and the GPI locus in the Hluhluwe population.

Of 45 cases of polymorphism, involving all loci and populations, $15(33.33 \%)$ were shown to exhibit genotype frequencies differing significantly from those expected under Hardy-Weinberg equilibrium (Table 2). Pooling of genotype frequencies brought about conformation with Hardy-Weinberg expectations in three of the cases: the PEP-GL locus ( $\mathrm{P}=0.073)$ in the Coleford, the PGM locus $(\mathrm{P}=0.109)$ in the University of Zululand $\mathrm{A}$, and the GPI locus $(\mathrm{P}=0.886)$ in the Oliviershoek B populations.

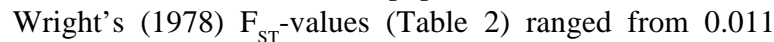
(indicating slight population sub-structuring) at the MDH-1 locus, to 1.000 (indicating fixed allelic differences between populations) at the ARK, ME and MPI loci. The mean $\mathrm{F}_{\mathrm{ST}}$ across all loci was 0.880 , illustrating significant genetic subdivision among popu-

\begin{tabular}{|c|c|c|c|c|c|c|c|c|c|c|c|c|c|c|c|}
\hline \multicolumn{16}{|c|}{$\begin{array}{l}\text { TABLE } 2 \\
\text { Allele frequencies of populations (specific cases where genotype frequencies deviate from Hardy- } \\
\text { Weinberg equilibrium indicated by asterices), and } F_{\mathrm{ST}} \text { at each of the polymorphic loci. } \\
\text { (1) Oliviershoek A, (2) Mahai A, (3) Tendele, (4) Kamberg, (5) Coleford, (6) Zululand A, (7) Mdibi, (8) } \\
\text { Mapelane, (9) Zululand B, (10) Hluhluwe, (11) Blood, (12) Oliviershoek B, (13) Mahai B, and (14) Mgeni. }\end{array}$} \\
\hline \multirow[t]{2}{*}{ Locus } & \multirow[t]{2}{*}{$\mathrm{F}_{\mathrm{ST}}$} & \multicolumn{14}{|c|}{ Populations } \\
\hline & & 1 & 2 & 3 & 4 & 5 & 6 & 7 & 8 & 9 & 10 & 11 & 12 & 13 & 14 \\
\hline ARK & 1.000 & & & & & & & & & & & & & & \\
\hline$N$ & & 24 & 43 & 12 & 18 & 53 & 56 & 26 & 25 & 13 & 13 & 7 & 15 & 16 & 21 \\
\hline 100 & & 0.000 & 0.000 & 0.000 & 1.000 & 1.000 & 1.000 & 1.000 & 1.000 & 1.000 & 1.000 & 1.000 & 1.000 & 1.000 & 1.000 \\
\hline 75 & & 1.000 & 1.000 & 1.000 & 0.000 & 0.000 & 0.000 & 0.000 & 0.000 & 0.000 & 0.000 & 0.000 & 0.000 & 0.000 & 0.000 \\
\hline GPI & 0.796 & & & & & & $*$ & & & & & & $* * *$ & & \\
\hline$N$ & & 24 & 43 & 12 & 18 & 53 & 56 & 26 & 25 & 13 & 13 & 7 & 15 & 16 & 21 \\
\hline 195 & & 0.000 & 0.000 & 0.000 & 0.278 & 0.000 & 0.000 & 0.000 & 0.000 & 0.000 & 0.000 & 0.000 & 0.000 & 0.000 & 0.000 \\
\hline 165 & & 0.000 & 0.000 & 0.000 & 0.000 & 0.000 & 0.045 & 0.000 & 0.000 & 0.000 & 0.000 & 0.000 & 0.000 & 0.000 & 1.000 \\
\hline 150 & & 0.000 & 0.000 & 0.000 & 0.000 & 0.000 & 0.000 & 0.000 & 0.000 & 0.000 & 0.038 & 0.000 & 0.000 & 0.000 & 0.000 \\
\hline 100 & & 1.000 & 1.000 & 1.000 & 0.722 & 0.991 & 0.000 & 0.000 & 0.000 & 0.000 & 0.038 & 0.000 & 0.067 & 0.063 & 0.000 \\
\hline 40 & & 0.000 & 0.000 & 0.000 & 0.000 & 0.009 & 0.938 & 1.000 & 1.000 & 0.962 & 0.846 & 1.000 & 0.400 & 0.219 & 0.000 \\
\hline-80 & & 0.000 & 0.000 & 0.000 & 0.000 & 0.000 & 0.018 & 0.000 & 0.000 & 0.038 & 0.077 & 0.000 & 0.533 & 0.719 & 0.000 \\
\hline HEX & 0.966 & & & & & $* * *$ & & & & & & & & & \\
\hline$N$ & & 24 & 43 & 12 & 18 & 31 & 41 & 26 & 25 & 13 & 13 & 7 & 15 & 16 & 5 \\
\hline 105 & & 0.000 & 0.000 & 0.000 & 0.000 & 0.129 & 0.000 & 0.000 & 0.000 & 0.000 & 0.000 & 0.000 & 0.000 & 0.000 & 0.000 \\
\hline 100 & & 1.000 & 1.000 & 1.000 & 1.000 & 0.871 & 1.000 & 1.000 & 1.000 & 0.000 & 0.000 & 0.000 & 0.000 & 0.000 & 1.000 \\
\hline 95 & & 0.000 & 0.000 & 0.000 & 0.000 & 0.000 & 0.000 & 0.000 & 0.000 & 1.000 & 1.000 & 1.000 & 1.000 & 1.000 & 0.000 \\
\hline
\end{tabular}




\begin{tabular}{|c|c|c|c|c|c|c|c|c|c|c|c|c|c|c|c|}
\hline IDH-1 & 0.920 & & & & & & & & & & & $* * *$ & & $* *$ & \\
\hline$N$ & & 15 & 38 & 12 & 18 & 41 & 41 & 26 & 25 & 13 & 7 & 7 & 15 & 15 & 5 \\
\hline 150 & & 0.000 & 0.000 & 0.000 & 0.000 & 0.000 & 0.000 & 0.000 & 0.000 & 1.000 & 0.929 & 0.857 & 1.000 & 0.733 & 0.000 \\
\hline 135 & & 0.033 & 0.000 & 0.000 & 0.000 & 0.000 & 1.000 & 1.000 & 1.000 & 0.000 & 0.071 & 0.143 & 0.000 & 0.267 & 0.000 \\
\hline 130 & & 0.000 & 0.000 & 0.000 & 0.000 & 0.000 & 0.000 & 0.000 & 0.000 & 0.000 & 0.000 & 0.000 & 0.000 & 0.000 & 1.000 \\
\hline 120 & & 0.967 & 0.987 & 1.000 & 0.000 & 0.000 & 0.000 & 0.000 & 0.000 & 0.000 & 0.000 & 0.000 & 0.000 & 0.000 & 0.000 \\
\hline 100 & & 0.000 & 0.013 & 0.000 & 1.000 & 1.000 & 0.000 & 0.000 & 0.000 & 0.000 & 0.000 & 0.000 & 0.000 & 0.000 & 0.000 \\
\hline IDH-2 & 0.827 & & & & & & & & & & & & $*$ & $*$ & \\
\hline$N$ & & 24 & 43 & 12 & 18 & 43 & 41 & 24 & 25 & 13 & 13 & 7 & 15 & 16 & 5 \\
\hline 120 & & 0.000 & 0.000 & 0.000 & 0.000 & 0.000 & 0.012 & 0.729 & 0.380 & 0.000 & 0.000 & 0.000 & 0.000 & 0.000 & 0.000 \\
\hline 100 & & 0.000 & 0.000 & 0.000 & 1.000 & 1.000 & 0.000 & 0.000 & 0.000 & 0.000 & 0.000 & 0.000 & 0.000 & 0.031 & 0.000 \\
\hline 80 & & 0.000 & 0.000 & 0.000 & 0.000 & 0.000 & 0.988 & 0.229 & 0.000 & 1.000 & 1.000 & 1.000 & 0.633 & 0.719 & 0.000 \\
\hline 60 & & 1.000 & 1.000 & 1.000 & 0.000 & 0.000 & 0.000 & 0.000 & 0.000 & 0.000 & 0.000 & 0.000 & 0.000 & 0.000 & 0.000 \\
\hline 45 & & 0.000 & 0.000 & 0.000 & 0.000 & 0.000 & 0.000 & 0.042 & 0.620 & 0.000 & 0.000 & 0.000 & 0.367 & 0.250 & 1.000 \\
\hline MDH-1 & 0.011 & & & & & & & & & & & & & & \\
\hline$N$ & & 24 & 43 & 12 & 18 & 43 & 41 & 26 & 25 & 13 & 13 & 7 & 15 & 16 & 5 \\
\hline 100 & & 1.000 & 1.000 & 1.000 & 1.000 & 1.000 & 0.988 & 1.000 & 1.000 & 1.000 & 1.000 & 1.000 & 1.000 & 1.000 & 1.000 \\
\hline 90 & & 0.000 & 0.000 & 0.000 & 0.000 & 0.000 & 0.012 & 0.000 & 0.000 & 0.000 & 0.000 & 0.000 & 0.000 & 0.000 & 0.000 \\
\hline MDH-2 & 0.967 & & & & & & & & & & & & & & \\
\hline$N$ & & 24 & 43 & 12 & 18 & 43 & 41 & 26 & 25 & 13 & 13 & 7 & 15 & 16 & 5 \\
\hline 125 & & 0.000 & 0.000 & 0.000 & 0.000 & 0.012 & 0.000 & 0.000 & 0.000 & 0.000 & 0.000 & 0.000 & 0.000 & 0.031 & 0.000 \\
\hline 100 & & 0.000 & 0.000 & 0.000 & 1.000 & 0.988 & 1.000 & 1.000 & 1.000 & 0.962 & 1.000 & 1.000 & 1.000 & 0.969 & 1.000 \\
\hline 75 & & 1.000 & 1.000 & 1.000 & 0.000 & 0.000 & 0.000 & 0.000 & 0.000 & 0.000 & 0.000 & 0.000 & 0.000 & 0.000 & 0.000 \\
\hline 65 & & 0.000 & 0.000 & 0.000 & 0.000 & 0.000 & 0.000 & 0.000 & 0.000 & 0.038 & 0.000 & 0.000 & 0.000 & 0.000 & 0.000 \\
\hline $\mathrm{ME}$ & 1.000 & & & & & & & & & & & & & & \\
\hline$N$ & & 24 & 43 & 12 & 18 & 53 & 56 & 26 & 25 & 13 & 13 & 7 & 15 & 16 & 15 \\
\hline 100 & & 1.000 & 1.000 & 1.000 & 1.000 & 1.000 & 0.000 & 0.000 & 0.000 & 0.000 & 0.000 & 0.000 & 0.000 & 0.000 & 0.000 \\
\hline 90 & & 0.000 & 0.000 & 0.000 & 0.000 & 0.000 & 1.000 & 1.000 & 1.000 & 1.000 & 1.000 & 1.000 & 1.000 & 1.000 & 1.000 \\
\hline MPI & 1.000 & & & & & & & & & & & & & & \\
\hline$N$ & & 24 & 43 & 12 & 18 & 53 & 41 & 26 & 25 & 13 & 13 & 7 & 15 & 16 & 15 \\
\hline 105 & & 0.000 & 0.000 & 0.000 & 0.000 & 0.000 & 1.000 & 1.000 & 1.000 & 1.000 & 1.000 & 1.000 & 1.000 & 1.000 & 1.000 \\
\hline 100 & & 1.000 & 1.000 & 1.000 & 1.000 & 1.000 & 0.000 & 0.000 & 0.000 & 0.000 & 0.000 & 0.000 & 0.000 & 0.000 & 0.000 \\
\hline PEP-GL & 0.752 & & & & & $* * *$ & & & & & & & & & $* * *$ \\
\hline$N$ & & 22 & 42 & 12 & 18 & 49 & 41 & 26 & 25 & 13 & 13 & 7 & 15 & 16 & 21 \\
\hline 115 & & 0.000 & 0.000 & 0.000 & 0.000 & 0.031 & 0.000 & 0.000 & 0.000 & 0.000 & 0.000 & 0.000 & 0.000 & 0.000 & 0.048 \\
\hline 110 & & 0.523 & 0.607 & 0.250 & 0.000 & 0.020 & 0.000 & 0.000 & 0.000 & 0.000 & 0.000 & 0.000 & 0.000 & 0.000 & 0.000 \\
\hline 100 & & 0.477 & 0.393 & 0.750 & 1.000 & 0.929 & 0.000 & 0.000 & 0.000 & 0.000 & 0.000 & 0.000 & 0.000 & 0.000 & 0.952 \\
\hline 90 & & 0.000 & 0.000 & 0.000 & 0.000 & 0.020 & 1.000 & 0.962 & 1.000 & 1.000 & 1.000 & 1.000 & 0.267 & 0.156 & 0.000 \\
\hline 75 & & 0.000 & 0.000 & 0.000 & 0.000 & 0.000 & 0.000 & 0.038 & 0.000 & 0.000 & 0.000 & 0.000 & 0.733 & 0.844 & 0.000 \\
\hline PEP-LT-1 & 0.997 & & & & & & & & & & & & & & \\
\hline$N$ & & 24 & 43 & 12 & 18 & 53 & 41 & 26 & 25 & 13 & 13 & 7 & 15 & 16 & 6 \\
\hline 100 & & 1.000 & 1.000 & 1.000 & 1.000 & 0.991 & 0.000 & 0.000 & 0.000 & 0.000 & 0.000 & 0.000 & 0.000 & 0.000 & 1.000 \\
\hline 95 & & 0.000 & 0.000 & 0.000 & 0.000 & 0.009 & 1.000 & 1.000 & 1.000 & 1.000 & 1.000 & 1.000 & 1.000 & 1.000 & 0.000 \\
\hline PEP-LT-2 & 0.713 & & & & & $* * *$ & $* * *$ & & & & & & $* * *$ & $* *$ & \\
\hline$N$ & & 24 & 43 & 12 & 18 & 43 & 41 & 26 & 25 & 13 & 13 & 7 & 15 & 16 & 6 \\
\hline$>250$ & & 0.000 & 0.000 & 0.000 & 0.000 & 0.023 & 0.000 & 0.000 & 0.000 & 0.000 & 0.000 & 0.000 & 0.000 & 0.000 & 0.000 \\
\hline 250 & & 0.000 & 0.000 & 0.000 & 0.000 & 0.023 & 0.049 & 0.019 & 0.020 & 0.000 & 0.000 & 0.000 & 0.033 & 0.094 & 0.000 \\
\hline 100 & & 0.000 & 0.000 & 0.000 & 1.000 & 0.953 & 0.854 & 0.885 & 0.840 & 0.923 & 0.769 & 1.000 & 0.833 & 0.906 & 1.000 \\
\hline 0 & & 0.000 & 0.000 & 0.000 & 0.000 & 0.000 & 0.098 & 0.096 & 0.140 & 0.077 & 0.231 & 0.000 & 0.133 & 0.000 & 0.000 \\
\hline-75 & & 1.000 & 1.000 & 1.000 & 0.000 & 0.000 & 0.000 & 0.000 & 0.000 & 0.000 & 0.000 & 0.000 & 0.000 & 0.000 & 0.000 \\
\hline PGM & 0.724 & & & & & & $*$ & & & & & & $* *$ & & \\
\hline$N$ & & 24 & 43 & 12 & 18 & 49 & 52 & 26 & 25 & 13 & 13 & 7 & 15 & 16 & 10 \\
\hline 110 & & 0.000 & 0.000 & 0.000 & 0.000 & 0.000 & 0.365 & 0.000 & 0.000 & 0.000 & 0.000 & 0.000 & 0.000 & 0.000 & 0.000 \\
\hline 100 & & 0.000 & 0.012 & 0.000 & 1.000 & 1.000 & 0.212 & 0.000 & 0.000 & 0.038 & 0.038 & 0.071 & 0.033 & 0.000 & 0.000 \\
\hline 90 & & 1.000 & 0.988 & 1.000 & 0.000 & 0.000 & 0.423 & 1.000 & 1.000 & 0.923 & 0.962 & 0.929 & 0.800 & 1.000 & 1.000 \\
\hline 75 & & 0.000 & 0.000 & 0.000 & 0.000 & 0.000 & 0.000 & 0.000 & 0.000 & 0.038 & 0.000 & 0.000 & 0.167 & 0.000 & 0.000 \\
\hline \multicolumn{16}{|c|}{$\begin{array}{l}N=\text { sample size } \\
* \mathrm{P}<0.05 ; * * \mathrm{P}<0.01 ; * * * \mathrm{P}<0.001\end{array}$} \\
\hline
\end{tabular}


TABLE 3

Sample sizes and mean genetic variability measures of the populations studied. Standard errors are included in parentheses

\begin{tabular}{|l|c|c|c|c|c|}
\hline & \multirow{2}{*}{$\begin{array}{c}\text { Mean sample size } \\
\text { per locus }\end{array}$} & $\begin{array}{c}\text { Mean number } \\
\text { of alleles } \\
\text { per locus }\end{array}$ & \multicolumn{2}{|c|}{$\begin{array}{c}\text { Percentage polymorphic } \\
\text { loci }\end{array}$} & $\begin{array}{c}\text { Mean expected } \\
\text { heterozygosity }\end{array}$ \\
\cline { 5 - 5 } & & & $\begin{array}{c}\mathbf{( 0 . 9 5} \\
\text { criterion) }\end{array}$ & \\
criterion) & \\
\hline Oliviershoek A & $23.21(0.65)$ & $1.14(0.10)$ & 14.29 & 7.14 & $0.041(0.036)$ \\
Mahai A & $42.57(0.36)$ & $1.21(0.11)$ & 21.43 & 7.14 & $0.038(0.034)$ \\
Tendele & $12.00(0.00)$ & $1.07(0.07)$ & 7.14 & 7.14 & $0.028(0.028)$ \\
Kamberg & $18.00(0.00)$ & $1.07(0.07)$ & 7.14 & 7.14 & $0.029(0.029)$ \\
Coleford & $46.79(1.73)$ & $1.64(0.25)$ & 42.86 & 14.29 & $0.037(0.018)$ \\
Univ. Zululand A & $46.07(1.91)$ & $1.57(0.23)$ & 35.71 & 21.43 & $0.077(0.048)$ \\
Mdibi & $25.86(0.14)$ & $1.36(0.20)$ & 21.43 & 14.29 & $0.051(0.033)$ \\
Mapelane & $25.00(0.00)$ & $1.21(0.15)$ & 14.29 & 14.29 & $0.054(0.038)$ \\
Univ. Zululand B & $13.00(0.00)$ & $1.36(0.17)$ & 28.57 & 14.29 & $0.032(0.015)$ \\
Hluhluwe & $12.57(0.43)$ & $1.43(0.23)$ & 28.57 & 21.43 & $0.063(0.032)$ \\
Blood & $7.00(0.00)$ & $1.14(0.10)$ & 14.29 & 14.29 & $0.029(0.021)$ \\
Oliviershoek B & $15.00(0.00)$ & $1.57(0.23)$ & 35.71 & 35.71 & $0.150(0.058)$ \\
Mahai B & $15.93(0.07)$ & $1.57(0.20)$ & 42.86 & 35.71 & $0.128(0.049)$ \\
Mgeni & $11.50(1.90)$ & $1.07(0.07)$ & 7.14 & 0.00 & $0.007(0.007)$ \\
& & & & & \\
\hline
\end{tabular}

Similarity (Unbiased genetic identity)
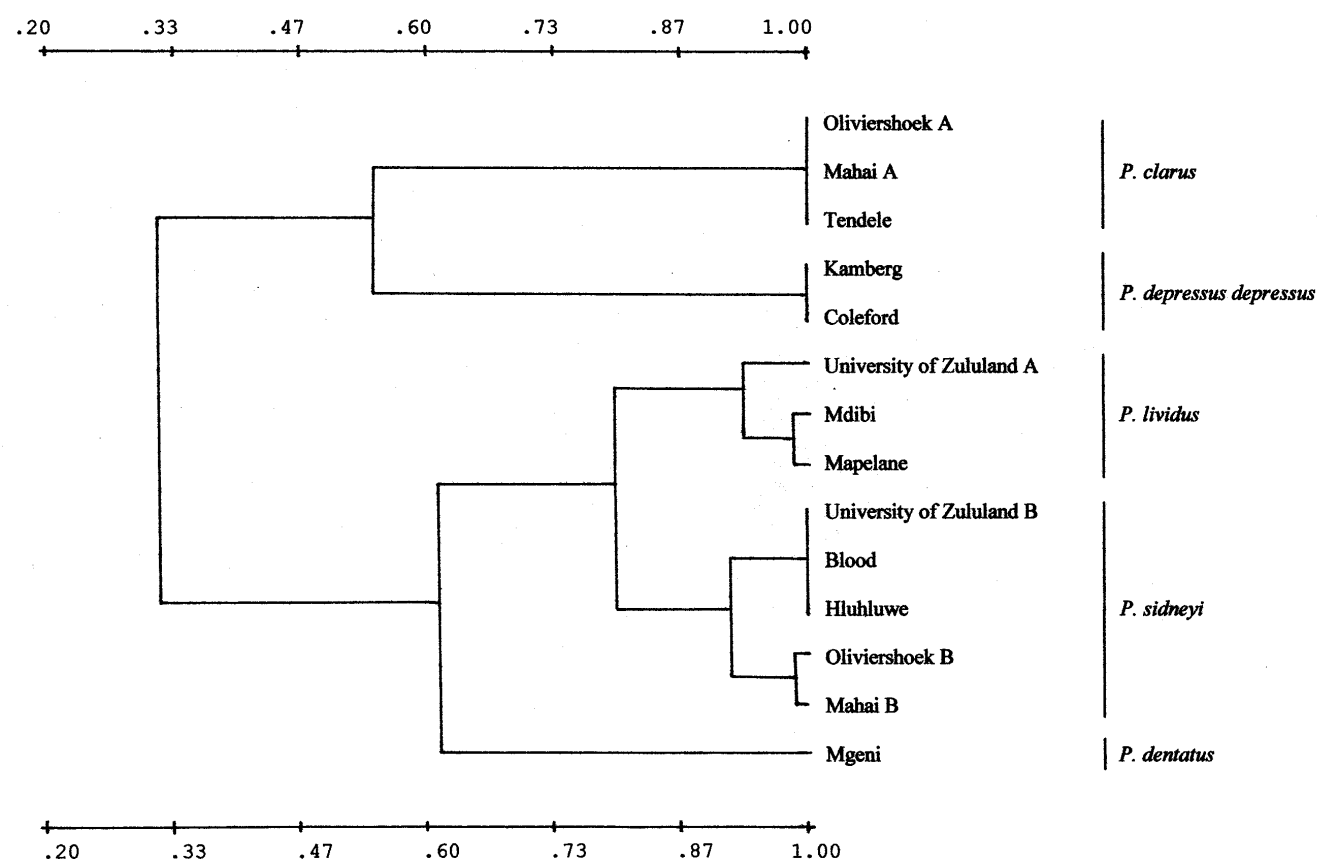

Figure 2

UPGMA-dendrogram constructed from the matrix of genetic identities (1) for pairwise comparisons of the populations studied

lations. Genetic variability differed greatly among populations (Table 3). The percentage of polymorphic loci ranged from $7.14 \%$ in the Tendele and Kamberg populations to $42.86 \%$ in the Coleford and Mahai B (P. sidneyi) populations using no criterion, and between $0.00 \%$ (in the Mgeni population) and $35.71 \%$ (Oliviershoek $\mathrm{B}$ and Mahai B populations), using the 0.95 criterion. Mean unbiased expected heterozygosity ranged from 0.007 in the Mgeni population to 0.150 in the Oliviershoek B ( $P$. sidneyi) population. The mean number of alleles per locus varied between 1.07 (in the Tendele, Kamberg and Mgeni populations) and 1.64 (in the Coleford population).
The dendrogram of genetic similarity (Fig. 2), constructed from the matrix (Table 4) of unbiased genetic identities (Nei, 1978) obtained from pair-wise comparisons of populations, revealed five distinct groups, formed by the five species present in the province.

These five groups, in turn, separated to form two clusters; one including the Potamonautes clarus and $P$. depressus depressus populations, and the other comprising the $P$. lividus, $P$. sidney $i$ and $P$. dentatus populations. These two clusters separated at an $I$-value of $0.326(D=1.163)$. This separation was primarily attributed to fixed allele differences between these two groups at the ME and MPI loci. Strong heterogeneity was also observed at the IDH-1, 
IDH-2 and PEP-LT-2 loci, the two groups being nearly fixed for alternate alleles or sets of alleles.

Within the cluster formed by populations of $P$. clarus and $P$. depressus depressus, the two species were shown to separate at an identity-value of $0.542(D=0.613)$. This separation is due to the occurrence of fixed allele differences at four loci (ARK, IDH-2, MDH-2 and PEP-LT-2) and strong heterogeneity at another two (IDH-1 and PGM) between populations of the two species. Within P. clarus, comparisons of populations yielded $I$-values of between 0.991 and $1.000(D=0.000$ to 0.009$)$, while an $I$-value of $0.994(D=0.006)$ was obtained in the comparison of the two $P$. depressus depressus populations.

The Potamonautes dentatus population, from the Mgeni River, branched off from the cluster containing the $P$. sidneyi and $P$. lividus populations at an $I$-value of 0.617 $(D=0.485)$. The $P$. dentatus population was distinguished from the remaining ( $P$. sidneyi and $P$. lividus) populations due to fixed allele differences at the IDH-1 and PEP-GL loci, as well as strong heterogeneity at the GPI locus.

Lastly, the $P$. sidneyi populations separated from the $P$. lividus populations at an $I$-value of $0.793(D=0.233)$. This was primarily due to the effect of a fixed allele difference at the HEX locus and heterogeneity at the IDH1 and -2 loci between these two species. Intraspecific $I$-values ranging from 0.924 to $0.982(D=0.018$ to 0.079$)$ were obtained in comparisons of the $P$. lividus populations. While intraspecific $I$-values ranged from 0.897 to 0.999 ( $D=0.001$ to 0.108 ) for comparisons of the $P$. sidneyi populations, the dendrogram clearly distinguished between the populations of $P$. sidneyi sampled from the highlands of the Drakensberg, and those sampled from the midlands and coastal areas. The $I$-value separating these two groups (the $P$. sidneyi populations from University of Zululand, Hluhluwe and the Blood River, and those from Oliviershoek and Mahai) was $0.914(D=0.090)$, and was due to significant allele frequency differences between these two groups at the GPI, IDH-2 and PEP-GL loci.

Average interspecific genetic identity-values and genetic distance-values were calculated from the matrix of pair-wise comparisons of populations of each species, and are presented in Table 5. The number of fixed allele differences which is evident in comparisons of these species, in this study, is also indicated. Interspecific identity-values ranged from $0.224(D=1.495)$ to $0.793(D$ $=0.233$ ), separating $P$. sidneyi from $P$. clarus and $P$. lividus, respectively. One fixed allele difference distinguished $P$. sidneyi and $P$. lividus, while nine were shown to separate these species from $P$. clarus. Two fixed allele differences separated sympatric populations of $P$. sidneyi and $P$. lividus, sampled from the University of Zululand campus. Ten fixed allele differences distinguished $P$. sidneyi and $P$. clarus populations found in sympatry at the Oliviershoek and Mahai localities.

\section{Morphometric analyses}

Potamonautes dentatus was easily identifiable from other species collected from the province owing to the presence of a series of teeth on the anterolateral margin of the carapace, the other species lacked this feature. Potamonutes sidneyi could be identified due to the robustness of the carapace, the possession of short, broad limbs, and by

\begin{tabular}{|c|c|c|c|}
\hline \multirow{15}{*}{ 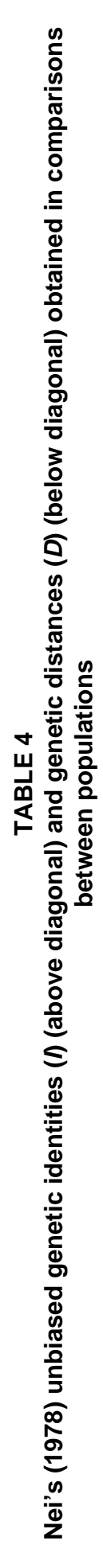 } & \multirow{14}{*}{\begin{tabular}{|l} 
\\
\\
\\
$\frac{0}{0}$ \\
$\frac{0}{5}$ \\
$\frac{0}{0}$ \\
0
\end{tabular}} & 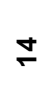 & 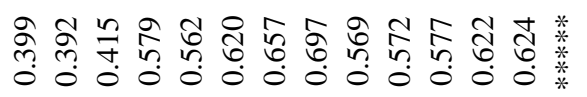 \\
\hline & & $\stackrel{m}{n}$ & 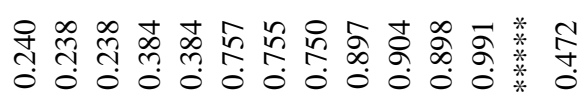 \\
\hline & & $\cong$ & 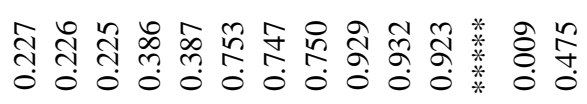 \\
\hline & & $=$ & 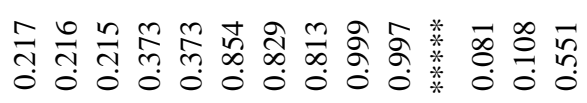 \\
\hline & & 으 & 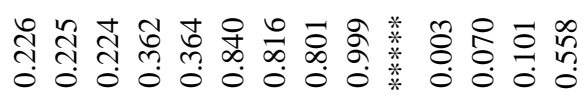 \\
\hline & & $a$ & 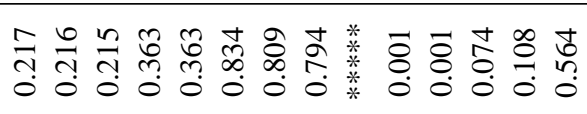 \\
\hline & & $\infty$ & 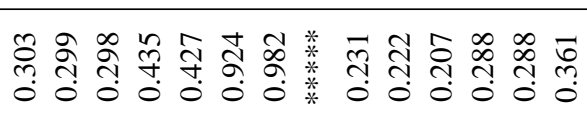 \\
\hline & & r & 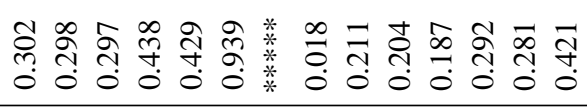 \\
\hline & & 0 & 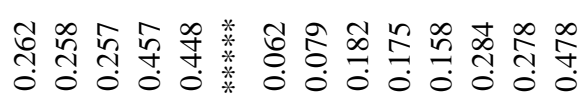 \\
\hline & & م & 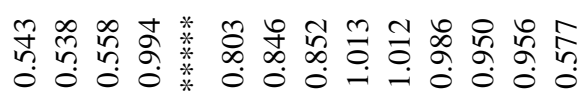 \\
\hline & & $\sigma$ & 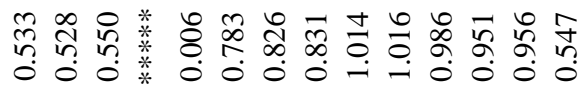 \\
\hline & & $m$ & 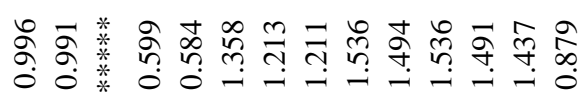 \\
\hline & & N & 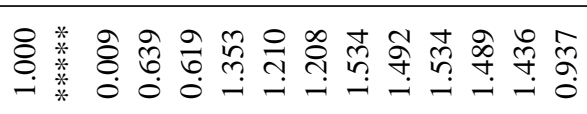 \\
\hline & & - & 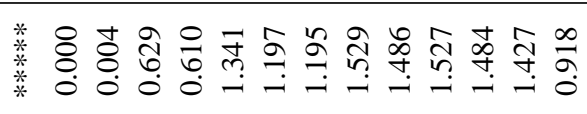 \\
\hline & & & 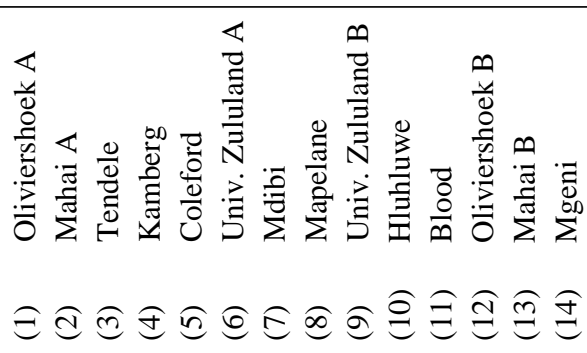 \\
\hline
\end{tabular}




\begin{tabular}{|c|c|c|c|c|c|}
\hline \multicolumn{6}{|c|}{$\begin{array}{c}\text { TABLE } 5 \\
\text { Mean interspecific genetic identity ( }() \text { and (in parentheses) distance }(D) \text { coefficients* for }^{\star} \\
\text { comparisons of the five species studied (above diagonal), and the number of fixed allelic } \\
\text { differences found in comparison of species (below diagonal) }\end{array}$} \\
\hline & \multicolumn{5}{|c|}{ Species } \\
\hline & P. clarus & P. depressus & P. lividus & P. sidneyi & P. dentatus \\
\hline P. clarus & $* * * * *$ & $0.542(0.613)$ & $0.286(1.254)$ & $0.224(1.495)$ & $0.402(0.911)$ \\
\hline P. depressus & 4 & $* * * * *$ & $0.439(0.824)$ & $0.374(0.984)$ & $0.571(0.562)$ \\
\hline P. lividus & 9 & 4 & $* * * * *$ & $0.793(0.233)$ & $0.658(0.420)$ \\
\hline P. sidneyi & 9 & 4 & 1 & $* * * * *$ & $0.593(0.524)$ \\
\hline P. dentatus & 8 & 6 & 3 & 5 & $* * * * *$ \\
\hline
\end{tabular}

TABLE 6

Classification functions calculated from the discriminant function analyses of five species of Potamonautes, using (a) carapace and (b) pereiopod variables

\begin{tabular}{|l|c|c|c|c|c|c|c|c|c|}
\hline Species & \multicolumn{7}{|c|}{ Variables } \\
\hline (a) & Log CL & Log CH & Log CWW & Log CWA & Log CWP & Log ED & Log PFCD & Constant \\
\hline P. depressus & -12.80 & -1356.47 & 2284.54 & 748.28 & -200.09 & -511.56 & -170.32 & & -946.58 \\
P. sidneyi & -12.63 & -1155.50 & 1830.23 & 950.27 & -193.77 & -463.98 & -158.37 & -816.78 \\
P. dentatus & -12.32 & -1350.02 & 2078.74 & 921.21 & -198.47 & -497.55 & -153.30 & -918.03 \\
$P$. lividus & -12.79 & -985.41 & 1733.34 & 858.74 & -167.47 & -496.14 & -158.74 & -733.22 \\
P. clarus & -13.22 & -1211.80 & 2205.23 & 667.74 & -203.61 & -500.55 & -162.32 & & -868.20 \\
\hline (b) & Log P5PW & Log P2MW & Log P2PW & Log P2PL & Log P5MW & Log P5PL & Log P2ML & Log P5ML & Constant \\
\hline P. depressus & -54.89 & 245.33 & -473.68 & -77.65 & 106.50 & -73.06 & 236.01 & 175.23 & 141.25 \\
$P$. sidneyi & -195.59 & 344.11 & -539.01 & -33.59 & 185.85 & -97.28 & 251.67 & 168.33 & -167.18 \\
P. dentatus & -106.34 & 306.02 & -542.87 & -37.95 & 141.30 & -104.47 & 258.04 & 176.18 & -167.45 \\
$P$. lividus & -230.33 & 324.84 & -500.85 & -24.43 & 158.62 & -95.96 & 271.47 & 160.72 & -159.49 \\
$P$. clarus & -141.88 & 268.55 & -444.14 & -88.06 & 117.11 & -77.95 & 259.41 & 179.13 & -142.98 \\
\hline
\end{tabular}

the typical granulation and beaded nature of the anterolateral and frontal carapace margins and scabrosity of the epibranchial corners. The surface of the carapace, and the anterolateral margins are smooth in Potamonautes lividus, $P$. depressus depressus and $P$. clarus. Potamonautes lividus could be identified by its highly inflated carapace, downward projecting frontal lobe and inflated chelipeds. The carapace and chelipeds of this species are bright orange to red in colour, while the carapace has a characteristic silver-blue sheen. Both P. depressus depressus and P. clarus are characterised by long slender limbs. They could be distinguished, however, by the bright orange colouration (with the tips of the chelipeds being lighter) typical of $P$. clarus. Potamonautes depressus depressus is commonly green-brown to yellow-brown. Further, $P$. clarus has a more robust, slightly more inflated carapace, the anterolateral margins of which are less rounded than those of $P$. depressus depressus.

The classification functions of the five species, calculated from the discriminant function analyses, using carapace variables and pereiopod variables, independently, are presented in Table 6 . With the exception of P5ML, all variables in both analyses contributed significantly to the discrimination between species. The variables $\mathrm{CL}, \mathrm{CH}$ and $\mathrm{CWW}$, and P5PW, P2MW and P2PW were the most discriminating in the analyses using carapace, and pereiopod variables, respectively.

The first two canonical variables calculated from the discriminant function analyses, using carapace variables, accounted for $98.13 \%$ of the variation between the species, and had Eigenvalues of 12.22 and 1.91, respectively. Individuals were plotted along these first two canonical variables (Fig. 3). Polygons encompassing individuals of each species falling within the 95\% confidence ellipse, showed virtually no overlap, indicating that each species was well differentiated with regard to the morphometrics of the carapace. This was also evident from the classification matrix (Table 7a), with cases being reassigned to groups, based on a posteriori probabilites. Potamonautes lividus $(98.03 \%$ correct reclassification) was well-defined with 149 of 152 individuals being reassigned to their original group, with three being assigned to the P. sidneyi group. Potamonautes depressus $(97.80 \%)$ and P. dentatus (96.08\%) were, similarly, well-defined, with 89 of 91 individuals and 49 of 51 individuals, respectively, being reassigned 


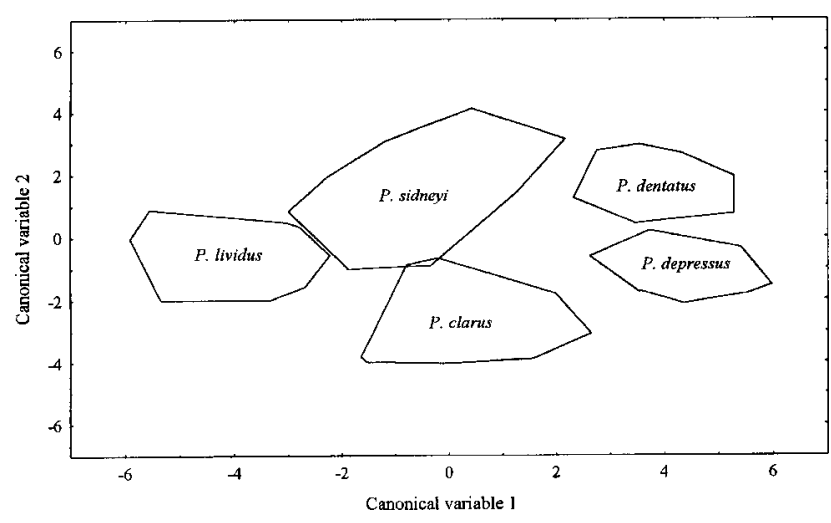

Figure 3

Polygons encompassing individuals of the five species studied, plotted along the first two canonical variables, as calculated from the discriminant function analysis using carapace variables

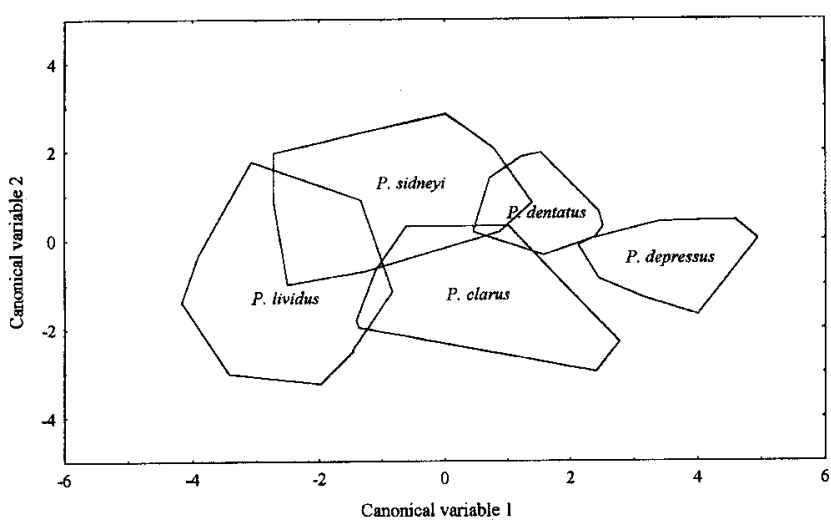

Figure 4

Polygons encompassing individuals of the five species studied, plotted along the first two canonical variables, as calculated from the discriminant function analysis using pereiopod variables

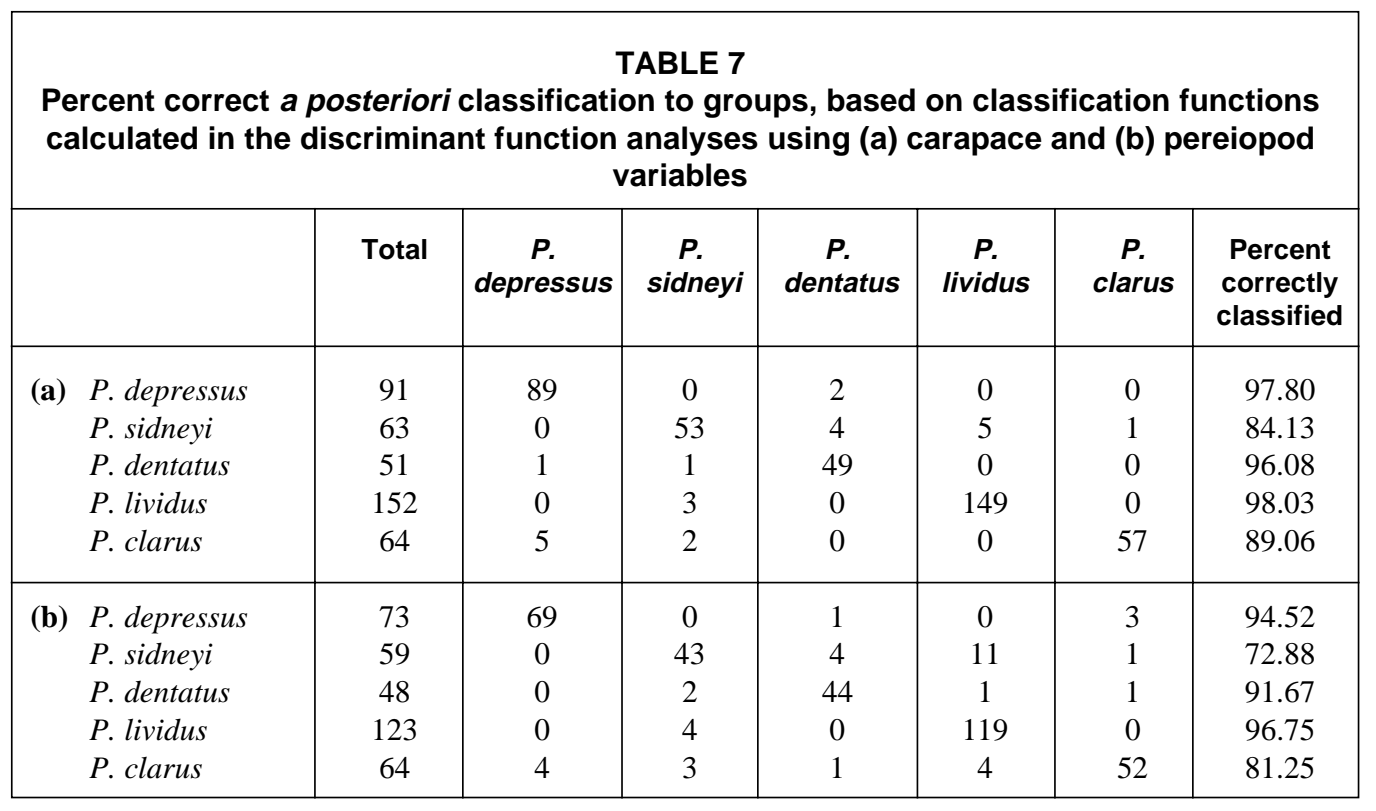

to their respective groups. Two individuals from the $P$. depressus depressus group were reassigned to $P$. dentatus, and one $P$. dentatus individual was reassigned to each of the $P$. sidneyi and $P$. depressus depressus groups. Of $63 P$. sidneyi individuals, 53 $(84.13 \%)$ were reassigned to the group, with five and four individuals, respectively, being reclassified as belonging to the $P$. lividus and $P$. dentatus groups. Seven of the $64 P$. lividus specimens were incorrectly reassigned: two to the $P$. sidneyi group, and five to $P$. depressus, leaving $57(89.06 \%)$ correctly classified.

Individuals of each species were also plotted two-dimensionally, based on scores along the first two canonical variables, calculated from the discriminant function analysis of eight pereiopod variables (Fig. 4). These two canonical variables accounted for $95.57 \%$ of the variation observed, and carried Eigen-values of 4.76 and 0.90 , respectively. The polygons encompassing individuals of each species, although showing limited overlap, revealed each species to be fairly well defined, in terms of pereiopod morphometrics. The greatest deal of overlap, and thus similarity in this respect, was observed between $P$. sidneyi and $P$. lividus. This distinction between species was also reflected in the classification matrix
(Table 7b). Of 123 P. lividus individuals, 119 (96.75\%) were reassigned to the group, with four being reclassified as $P$. sidneyi. Sixty-nine $(94.52 \%) P$. depressus individuals remained in that group, following reassignment, with one being classified as $P$. dentatus, and three as $P$. clarus. Of the $48 P$. dentatus individuals ( $91.67 \%$ correct reclassification), two were placed in the $P$. sidneyi group, and one into each of the $P$. lividus and $P$. clarus groups. Potamonautes clarus $(81.25 \%)$ and $P$. sidneyi $(72.88 \%)$ were less well defined. The classification matrix emphasises the difference in limb shape between the $P$. depressus $-P$. clarus group, distinguished by long slender limbs, and the remaining species, which typically possess shorter, stouter limbs: no $P$. sidneyi, $P$. dentatus and $P$. lividus individuals were reassigned to $P$. depressus, and only two were reassigned to $P$. clarus. Three $P$. depressus individuals were reassigned to $P$. clarus, and four vice versa. The low correct classification percentage in the case of $P$. sidneyi is due to the reassignment of individuals to the stout-limbed $P$. lividus ( 11 of 59 individuals) and $P$. dentatus (4 of 59), as well as $P$. clarus (one individual). 


\section{Distribution}

Generalised distribution maps, based on collection data from the 220 localities, were drafted for each of the five species known from KwaZulu-Natal and are illustrated in Figs. 5 to 9.

\section{Discussion}

\section{Diversity and distribution}

The recent description of three new species; $P$. dentatus (Stewart et al., 1995), P. clarus (Gouws et al., 2000) and P. lividus (Gouws et al., 2001), along with $P$. sidneyi and $P$. depressus depressus, brings the number of species known from KwaZulu-Natal to five, and brings the total number known from South Africa to 12 . Potamonautes dentatus appears to be endemic to the province. Further collections will, however, be needed to determine the endemicity of $P$. clarus, which may extend into the Free State and Mpumalanga, and $P$. lividus, which may extend into the lowveld of Mpumalanga and into Mozambique. Potamonautes sidneyi and $P$. depressus depressus are already known as relatively widespread species, extending into the Eastern Cape (Kensley, 1981), and in the case of $P$. sidneyi, extending further north (Kensley, 1981; Stewart and Cook, 1998).

Potamonautes clarus is known from the upper, faster flowing tributaries and headwaters of the Tugela River, in the vicinity of the Oliviershoek Pass and the Royal Natal National Park (Fig. 5), in the northern Drakensberg area. A single specimen has been collected from the Sterkfontein Dam in the Free State, near the summit of Van Reenen's Pass. The southernmost distribution extends to Cathedral Peak. The northern boundary of the distribution of the species may extend further into the Free State or into Mpumalanga. Potamonautes dentatus is an endemic species with a limited distribution (Fig. 6). Collections have been recorded from the Mgeni River, from below the Nagle Dam to the Howick Falls and the Albert Falls Dam. Further collections have been made from the Bushmans River (near Estcourt) and along the Mooi River, both in the Tugela River system.

Potamonautes depressus depressus has been recorded from the upper, fast-flowing tributaries of the Mzimvubu River, Mzimkulu River, Mkomasi River and Mgeni River, as well as the Mooi River, within the Tugela River system (Fig. 7). The species is thus widespread in the Drakensberg and its foothills, with the southernmost collections being recorded from the headwaters of the Mzimkulu River, and the northernmost collections being made at Highmoor Nature Reserve.

Potamonautes lividus is only known from three localities; the University of Zululand, Mdibi swamp forest and the Mapelane Nature Reserve (Fig. 8) in north-eastern KwaZulu-Natal. A possible fourth population has been documented from the Amatikulu River, marking the southernmost point of the species distribution. The species appears to be restricted to small patches of swamp forest, characterised by hydromorphic peat soil, and vegetation assemblages including Syzigium cordatum, Ficus trichopoda and Barringtonia racemosa. Specimens of uncertain identity, but resembling $P$. lividus, have been collected further north than the Mapelane Nature Reserve; from the Mkuze Game Reserve, False Bay Park, Ntambanana, Mtubatuba and Hluhluwe Game Reserve. These require further investigation.

Populations of $P$. sidneyi were collected as far north as Lake Sibayi and as far south as Port Shepstone and the Weza State Forest. The species is thus widespread across the province (Fig. 9), as noted by Stewart et al. (1995). No specimens were recorded from the

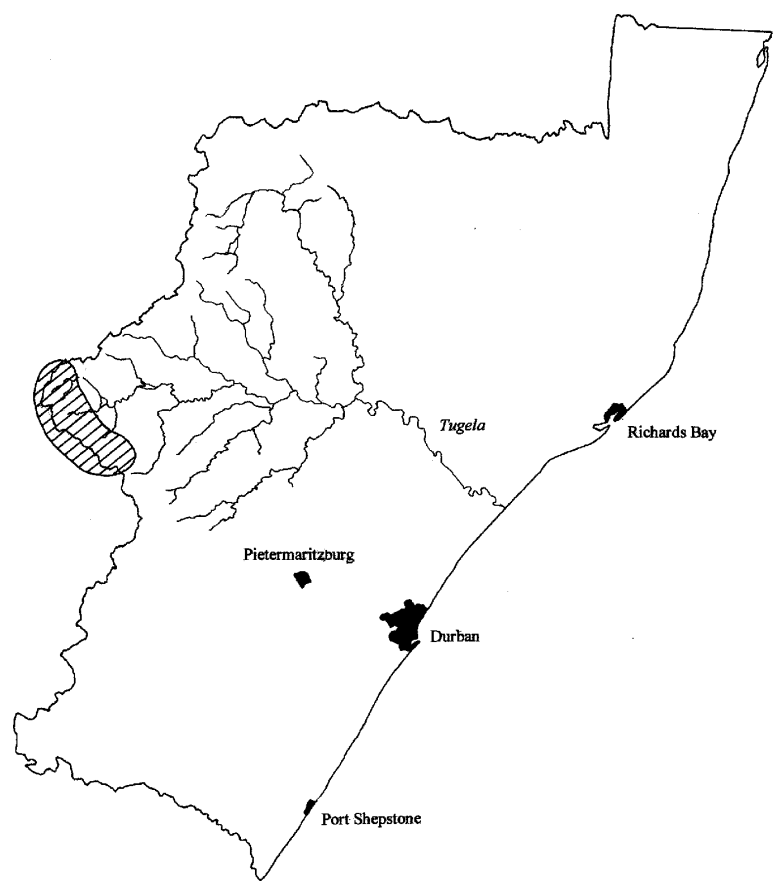

Figure 5

The distribution of Potamonautes clarus in KwaZulu-Natal

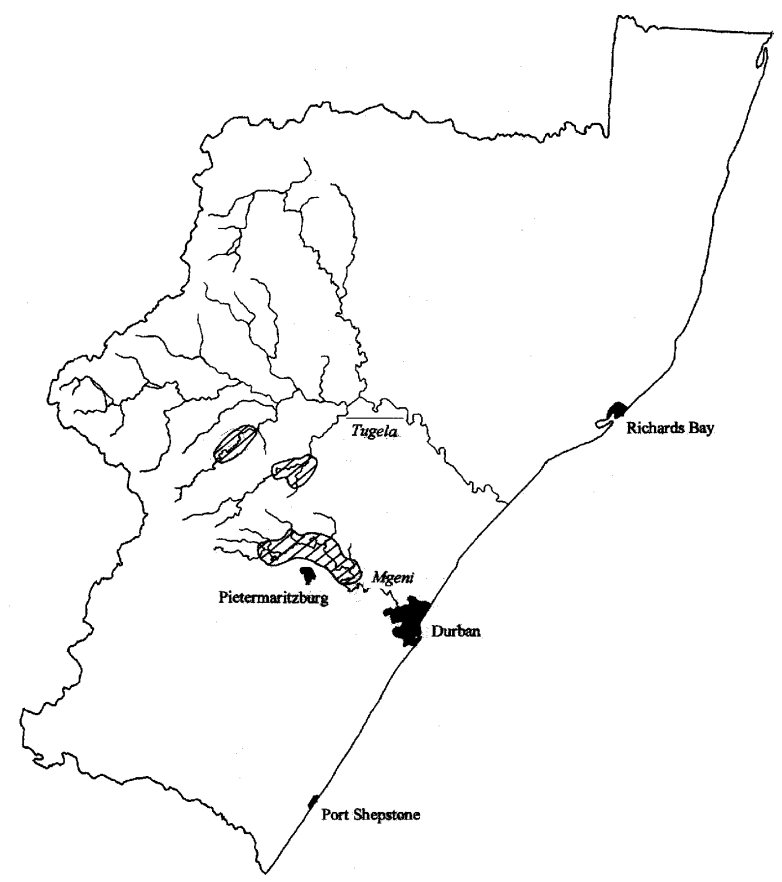

Figure 6

The distribution of Potamonautes dentatus in KwaZulu-Natal

upper reaches and faster flowing tributaries of the Mzimkulu, Mzimvubu and Mkomasi Rivers, from which P. depressus depressus has been recorded. Generally, $P$. sidneyi is regarded to occur throughout the lowlying midlands region, from the foothills of the Drakensberg to the coast (Stewart et al., 1995). However, populations of $P$. sidneyi have been recorded, occurring sympatrically with $P$. clarus or $P$. $d$. depressus, from the faster flowing streams and upper tributaries of the Tugela River and Mgeni River, draining the Drakensberg and its foothills. The 


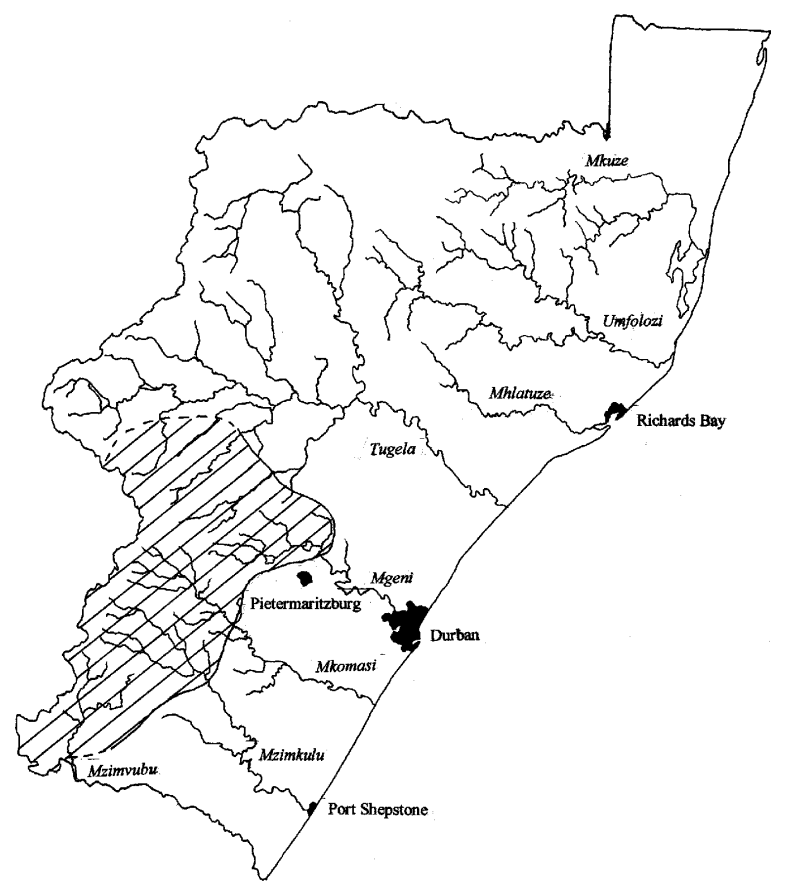

Figure 7

The distribution of Potamonautes depressus depressus in KwaZulu-Natal

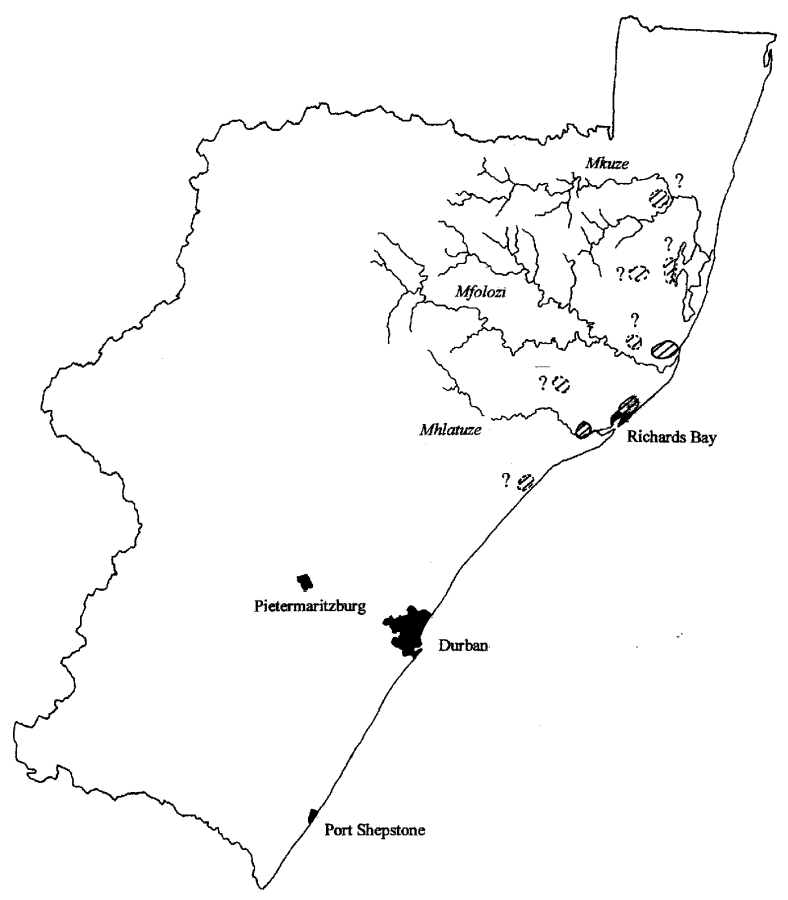

Figure 8

The distribution of Potamonautes lividus in KwaZulu-Natal

distribution of the species may have been facilitated into these upper drainages, by impoundments, such as the Woodstock, Kilburn, Driel and Spioenkop Dams in the Tugela River system and the Albert Falls Dam and Midmar Dam in the Mgeni River system.

\section{Differentiation within Potamonautes}

Levels of interspecific genetic differentiation obtained between species in this study, with the average $I$-values separating species

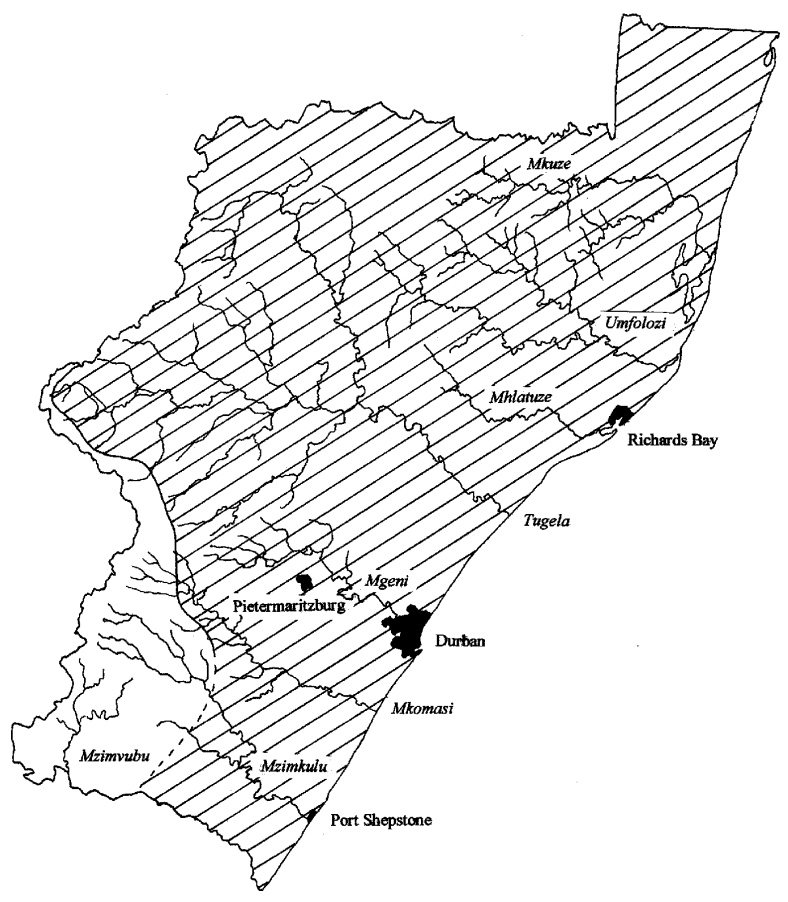

Figure 9

The distribution of Potamonautes sidneyi in KwaZulu-Natal

ranging between $0.793(D=0.233)$ and $0.224(D=1.495)$ were, generally, lower than values separating species within Potamonautes, obtained in other studies (Stewart, 1997a; b; Stewart and Cook, 1998; Daniels et al., 1999; Gouws et al., 2000; 2001). Stewart (1997a) obtained an average $I$-value of $0.68(D=0.39)$ separating P. perlatus and P. parvispina in the Western Cape. An identity-value of $0.66(D=0.42)$ was shown to distinguish $P$. perlatus and P. brincki, in the Western Cape (Stewart, 1997b), as well as $P$. unispinus and $P$. sidneyi in the Northern Province and Mpumalanga (Stewart and Cook, 1998). Potamonautes granularis and $P$. perlatus were separated by an identity-value of 0.88 $(D=0.13)$ (Daniels et al., 1999). The identity-value obtained in the comparison of $P$. clarus and $P$. depresus depressus $(I=0.542$, $D=0.613)$, is slightly lower than the $I$-value of $0.599(D=0.512)$ presented for the delineation of $P$. clarus from $P$. depressus depressus (Gouws et al., 2000). However, in this study 14 loci were included in the analysis, whereas 21 loci, the majority of the additional loci being monomorphic, were assayed in the latter study. The same is true of $P$. lividus, delineated from $P$. sidneyi based on an $I$-value of $0.829(D=0.187)$ (Gouws et al., 2001). The $I$-value for the same comparison of species in this study was 0.793 $(D=0.233)$. Only one fixed allele difference was observed between $P$. sidneyi and $P$. lividus in the initial genetic delineation (Gouws et al., 2001), considering the alleles present in all populations of the two species. When only the sympatric populations at the University of Zululand locality are considered, two fixed allele differences are revealed.

Interspecific identity-values obtained in this study, are comparable to interspecific values obtained in electrophoretic studies of a wide range of decapod Crustacea and invertebrate taxa (Hedgecock et al., 1982; Thorpe, 1982; Thorpe and Solé-Cava, 1994). Thorpe (1982) and Thorpe and Solé-Cava (1994) had stated that of $I$-values separating species within a genus $85 \%$ were above 0.35 , with $97 \%$ being below 0.85 . Further, Thorpe and Solé-Cava (1994) had stated that allopatric populations showing an $I$-value of less than 0.85 were unlikely to be conspecific. Hedgecock et al. 


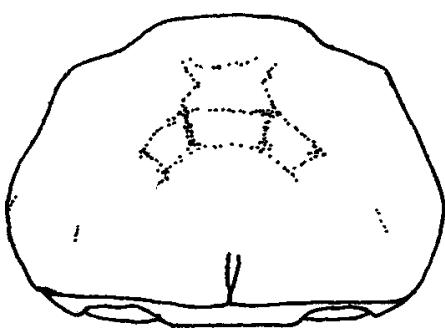

A Potamonautes clarus

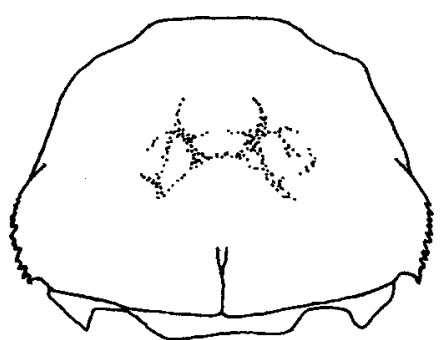

B Potamonautes dentatus

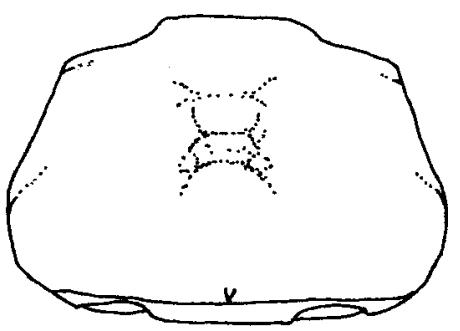

C Potamonautes depressus depressus

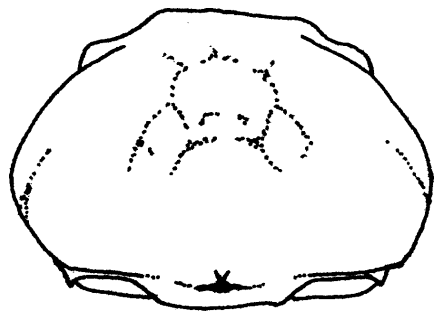

D Potamonautes lividus

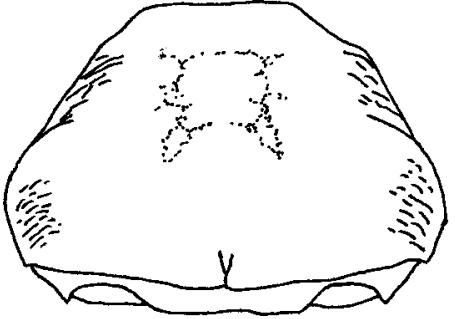

E Potamonautes sidneyi

Figure 10

Carapace outlines of the five Potamonautes species occurring in KwaZulu-Natal

(1982) had obtained an average $I$-value of 0.66 in comparisons of 26 congeneric decapod Crustacean species pairs.

Interestingly, the dendrogram grouped the Potamonautes clarus and $P$. depressus depressus populations together, separate to the cluster containing the $P$. sidneyi, $P$. lividus and $P$. dentatus populations. Both $P$. depressus depressus and $P$. clarus are species occurring in the upper tributaries and fast-flowing rivers and the streams of the Drakensberg highlands, and the high-altitude foothills. Both are characterised by long, slender limbs and relatively flattened carapaces. The remaining species, typically stout-limbed, have low-lying, middle- to lower-reach distributions. Although strictly only indicative of allozymic similarity, the dendrogram may indicate a shared evolutionary or phylogenetic history, by populations or species within each of these two clusters. However, in the absence of reliable phylogenetic or high-resolution molecular data, no definitive statements can be made in this regard.

Heterozygosity estimates obtained in the present study are relatively high in comparison to values obtained in other studies on Potamonautes (Daniels et al., 1998b; 1999). Estimates of heterozygosity are, however, known to be sensitive to small sample sizes, in terms of the number of individuals and number of loci studied, as well as the choice of loci (Nei and Roychoudhury, 1974; Nei, 1978; Simon and Archie, 1985).

Generally, intraspecific differentiation was low, with populations of most species being genetically invariant. This can be attributed to high levels of gene flow between populations, and seems typical of Potamonautes. Intraspecific $I$-values in this study, found to range from 0.897 to $1.000(D=0.000$ to 0.108$)$, were generally comparable to existing data. In seven studies, involving nine Potamonautes species from South Africa, intraspecific genetic identity-values were shown to be, typically, high, ranging from 0.902 to $1.000(D=0.000$ to 0.103$)$ (Stewart, 1997a; b; Stewart and Cook, 1998; Daniels et al., 1998b; 1999; Gouws et al., 2000; 2001). An average $I$-value of 0.75 was shown to separate two groups of $P$. brincki populations across the Cape Flats and Peninsula (Stewart, 1997b). Within each of these groups, however, comparisons between populations yielded $I$-values between $0.908(D=0.097)$ and $1.000(D=0.000)$, and it is probable that these groups represent two species, requiring further investigation (Stewart, 1997b).

Species were well distinguished, morphometrically, with the use of sensitive, high-powered multivariate analyses, using combinations of carapace or pereiopod variables. Carapace morphology has long been viewed as a useful and diagnostic taxonomic character. Species were primarily identified using carapace morphology in the earlier catalogues by Barnard (1935; 1950) and Bott (1955). Barnard (1935) raised doubts as to the validity of carapace morphology as a reliable taxonomic character when reporting the morphological transition between $P$. perlatus and $P$. sidneyi. However, most species known to occur in KwaZuluNatal could be identified by casual examination of carapace morphology alone (Fig. 10). Where identification based on carapace morphology was unreliable, such as distinguishing between $P$. clarus and $P$. depressus depressus, colour proved to be a reliable characteristic. Colour is, increasingly, being regarded as a valuable taxonomic feature in decapod Crustacean systematics (Knowlton, 1986; Knowlton and Mills, 1992; Daniels et al., 1998a).

Within the province of KwaZulu-Natal, much more work is needed. Relatively large areas remain unsampled, and many populations have not been analyzed genetically. Repeated sampling of the known localities will provide useful data on distribution changes and changes in population sizes, whether due to human activity or not. This will enable the making of informed decisions regarding the conservation of the invertebrate fauna, within the rivers of the province. The biology of freshwater river crabs has also been poorly studied. The presence of three new species from the province, one with apparently unique habitat requirements; and the great diversity of species and habitats in the province provide an opportunity for comparative physiological, ecological and behavioural studies. 


\section{Key for the identification of the Potamonautes species of KwaZulu-Natal}

1. Anterolateral margin of carapace bears a series of distinct teeth P. dentatus

Anterolateral margins of carapace smooth or granulated, teeth or spines absent ....................................................... 2

2. Post-frontal crest forms distinct angle at epibranchial corner on joining the anterolateral margin, epibranchial corners show scabrosity or granulation P. sidneyi

- Anterolateral margin rounded and smooth, epibranchial region of carapace smooth, without granulation or scabrosity

3. Carapace depressed and flattened dorsally, ratio of carapace length to height between $2.3-2.6$, post-frontal crest complete..... P. depressus depressus

- Carapace distinctly vaulted and arched, ratio of carapace length to height between $1.5-2.2$; post-frontal crest sometimes diminished medially 4

4. Carapace dark orange to red with distinct silver-blue sheen; tips of chelipeds orange to red ............................... P. lividus

- Carapace bright orange; tips of chelipeds lighter cream to yellow ...................................................................... P. clarus

\section{Acknowledgements}

The authors wish to express their gratitude to Mike Coke (KwaZuluNatal Nature Conservation Service) and Patrick Reavell (University of Zululand) for all their input. Funding was kindly provided by the WWF-SA (World Wildlife Fund) and the NRF (National Research Foundation). Thanks are due to the South African Museum, Transvaal Museum and Albany Museum for allowing the authors access to their collections, and to the KwaZulu-Natal Nature Conservation Service for providing logistical support and allowing access to their reserves. Tyrone Ridgway, Liz Hoenson and Peter Cook are thanked for their assistance in the field.

\section{References}

ARKELL GBF (1979) Aspects of the feeding and breeding biology of the giant kingfisher. Ostrich 50 177-181.

BALSS H (1922) Crustacea Decapoda. In: W Michaelson (ed.) Beiträge zur Kenntnis der Land-und Süsswasserfauna Deutsch.-Süd-westafrikas. Ergebnisse Hamburger deutsche-südwestafrikanischen Studienreise. 271-72.

BALSS H (1936) Beiträge zur Kenntnis der Potamonidae (Süsswasserkrabben) des Kongogebietes. Rev. Zool. Bot. Afr. 28 165-204.

BARNARD KH (1935) Scientific results of the Vernay-Lang Kalahari expedition, March to September, 1930: Crustacea. Annu. Transv. Mus. 16 481-492.

BARNARD KH (1950) Descriptive catalogue of South African decapod Crustacea (crabs and shrimps). Annu. S. Afr. Mus. 38 1-837.

BOTT R (1955) Die Süsswasserkrabben von Afrika (Crust., Decap.) und ihre Stammesgeschichte. Annu. Mus. R. Congo Belge C. Zool. $1(3,3)$ 209-352.

COLOSI G (1924) Potamonidés africains du Muséum de Stockholm. Ark. Zool. 16 (1) 1-24.

CUMBERLIDGE N (1989) Redescription of Sudanonautes orthostylis Bott, 1955, a freshwater crab from Nigeria, Cameroon and Ghana with notes on its ecology. Crustaceana 56 (3) 230-245.

CUMBERLIDGE N and CLARK PF (1992) A new genus and species of freshwater crab from Cameroon, West Africa (Crustacea, Brachyura, Potamoidea, Potamonautidae). Bull. Br. Mus. (Nat. Hist.) Zool. 58 (2) 149-156.

DANDY JWT and EWER DW (1961) The water economy of three species of the amphibious crab, Potamon. Trans. R. Soc. S. Afr. 36 (3) 137-162.

DANIELS SR, STEWART BA and GIBBONS MJ (1998a) Potamonautes granularis sp. nov. (Brachyura, Potamonautidae), a new cryptic species of river crab from the Olifants River system, South Africa. Crustaceana 71 (8) 885-903.
DANIELS SR, STEWART BA and GIBBONS MJ (1998b) Genetic and morphometric variation in the potamonautid river crab Potamonautes parvispina (Decapoda: Potamonautidae) from two Western Cape rivers, South Africa. J. Nat. Hist. 32 1245-1258.

DANIELS SR, STEWART BA and GIBBONS MJ (1999) Genetic structure among populations of Potamonautes perlatus (Decapoda: Potamonautidae) from the Olifants River system in the Western Cape, South Africa. J. Zool. (London) 249 (2) 137-142.

GOUWS G, STEWART BA and COKE M (2000) Evidence for a new species of river crab (Decapoda, Brachyura, Potamonautidae) from the Drakensberg, South Africa. J. Crust. Biol. 20 (4) 743-758.

GOUWS G, STEWART BA and REAVELL PE (2001) A new species of freshwater crab (Decapoda, Potamonautidae) from the swamp forests of KwaZulu-Natal, South Africa: Biochemical and morphological evidence. Crustaceana 74 (2).

HEDGECOCK D, TRACEY ML and NELSON K (1982) Genetics. In: L G Abele (ed.) The Biology of Crustacea (Volume 2). Academic Press, New York. 283-403.

HILGENDORF F (1898) Die Land- und Süsswasser-Dekapoden OstAfrikas. Die Thierwelt Deutsch Ost-Afrikas 4 (7) 1-37.

HILL MP and O'KEEFFE JH (1992) Some aspects of the ecology of the freshwater crab (Potamonautes perlatus Milne-Edwards) in the upper reaches of the Buffalo River, eastern Cape Province, South Africa. S. Afr. J. Aquat. Sci. $18(1 / 2) 42-50$.

KENSLEY B (1981) On the zoogeography of Southern African decapod Crustacea, with a distributional checklist of species. Smithson. Contrib. Zool. 338 1-64.

KNOWLTON N (1986) Cryptic and sibling species amongst the decapod Crustacea. J. Crust. Biol. 6 356-363.

KNOWLTON N and MILLS DEK (1992) The systematic importance of color and color pattern: Evidence for complexes of sibling species of snapping shrimp (Caridea: Alpheidea: Alpheus) from the Caribbean and Pacific coasts of Panama. Proc. San Diego Soc. Nat. Hist. 18 1-5.

KRAUSS F (1843) Südafrikanischen Crustaceen. Eine Zusammenstellung aller bekannten Malacostraca, Bemerkungen über deren Lebensweise und geographische Verbreitung, nebst Beschreibung und Abbildung mehrer neuen Arten. E. Schweizerbart'sche Verlagsbuchhandlung: Stuttgart.

LENZ-LÜBECK H (1912) Afrikanische Crustaceen aus schwedischen Sammlungen. Ark. Zool. 7 (29) 1-10

LEVENE H (1949) On a matching problem arising in genetics. Ann. Math. Stat. 20 91-94.

MABEE PM and HUMPHRIES J (1993) Coding polymorphic data: examples from allozymes and ontogeny. Syst. Biol. 42 (2) 166-181.

MARKERTCL andFAULHABER I (1965)Lactate dehydrogenase isozyme patterns of fish. J. Exp. Zool. 159 319-332.

NEI M (1978) Estimation of average heterozygosity and genetic distance from a small number of individuals. Genetics 89 583-590.

NEI M and ROYCHOUDHURY AK (1974) Sampling variances of heterozygosity and genetic distance. Genetics 76 379-390. 
PURVES MG, KRUUK H and NEL JAJ (1991) Crabs Potamonautes perlatus in the diet of otter Aonyx capensis and water mongoose Atilax paludinosus in a freshwater habitat in South Africa. Int. J. Mamm. Biol. 59 (6) 332-341.

RATHBUN MJ (1904) Les Crabes d'Eau Douce (Potamonidae). 1. Nouv. Arch. Mus. Hist. Nat. (Paris) 6 225-312.

RATHBUN MJ (1905) Les Crabes d'Eau Douce (Potamonidae). 2. Nouv. Arch. Mus. Hist. Nat. (Paris) 7 159-322.

RATHBUN MJ (1906) Les Crabes d'Eau Douce (Potamonidae). 3. Nouv. Arch. Mus. Hist. Nat. (Paris) 8 33-122.

RATHBUN MJ (1921) The Brachyuran crabs collected by the American Museum Congo Expedition, 1909-1915. Bull. Am. Mus. Nat. Hist. 43 379-466.

RIDGEWAY GJ, SHERBURNE SW and LEWIS RD (1970) Polymorphism in the esterase of Atlantic herring. Trans. Am. Fish. Soc. 99 147-151.

SACHS R and CUMBERLIDGE N (1991) First record of the spiny river crab, Liberonautes chaperi (A. Milne-Edwards 1887) as a second intermediate host of Paragonimus uterobilateralis in Liberia. Ann. Trop. Med. Paras. 85(4) 471-472.

SHAW CR and PRASAD RB (1970) Starch gel electrophoresis of enzymes - A compilation of recipes. Biochem. Gen. 4 297-320.

SIMON C and ARCHIE J (1985) An empirical demonstration of the lability of heterozygosity estimates. Evolution 39(2) 463-467.

SNEATH PHA and SOKAL RR (1973) Numerical Taxonomy (1st edn.) WH Freeman and Company, San Francisco.

SOKAL RR and ROHLF FJ (1981) Biometry (2nd edn.) WH Freeman and Company, New York.

STATSOFT INC (1996) STATISTICA for Windows. Tulsa, Oklahoma, USA.

STEBBING T (1910) General catalogue of South African Crustacea. Ann. S. Afr. Mus. 6 281-593.

STEENKAMP VE, DU PREEZ HH and SCHOONBEE HJ (1994) Bioaccumulation of copper in the tissues of Potamonautes warreni (Calman) (Crustacea, Decapoda, Brachyura) from industrial, mine and sewage polluted freshwater ecosystems. S. Afr. J. Zool. 29 (2) 152-161.

STEENKAMP VE, DU PREEZ HH, SCHOONBEE HJ, WIID AJB and BESTER MM (1993) Bioaccumulation of iron in the freshwater crab Potamonautes warreni from three industrial, mine and sewage polluted freshwater ecosystems in the Transvaal. Water SA 19 (4) 281-290.
STEVENS PM (1991) A genetic analysis of the pea crabs (Decapoda: Pinnotheridae) of New Zealand. II. Patterns and intensity of spatial population structure in Pinnotheres atrinicola. Mar. Biol. 108 403410.

STEWART BA (1997a) Biochemical and morphological evidence for a new species of river crab Potamonautes parvispina sp. nov. (Brachyura, Potamonautidae). Crustaceana 70 (6) 737-753.

STEWART BA(1997b) Morphological and genetic differentiation between populations of river crabs (Decapoda: Potamonautidae) from the Western Cape, South Africa, with a taxonomic re-examination of Gecarcinautes brincki. Zool. J. Linn. Soc. 119 1-21.

STEWART BA, COKE M and COOK PA (1995) Potamonautes dentatus, new species, a fresh-water crab (Brachyura: Potamoidea: Potamonautidae) from KwaZulu-Natal, South Africa. J. Crust. Biol. 15 (3) 558-568.

STEWART BA and COOK PA (1998) Identification of a new species of river crab (Decapoda: Brachyura: Potamonautidae) from South Africa using morphological and genetic data. J. Crust. Biol. 18 (3) 48-61.

SWOFFORD DL and SELANDER RB (1981) BIOSYS-1: A Computer Program for the Analysis of Allelic Variation in Population Genetics and Biochemical Systematics. Release 1.7. David L. Swofford, Illinois Natural History Survey, Illinois.

THORPE JP (1982) The molecular clock hypothesis: Biochemical evolution, genetic differentiation and systematics. Ann. Rev. Ecol. Syst. 13 139-168.

THORPE JP and SOLÉ-CAVA AM (1994) The use of allozyme electrophoresis in invertebrate systematics. Zool. Scr. 23 3-18.

THORPE RS (1976) Biometric analysis of geographic variation and racial affinities. Biol. Rev. 51 407-452.

THORPE RS (1988) An application of common principal component analysis to cranial morphology of Microtus californicus and $M$. ochrogaster (Mammalia, Rodentia): further remarks. J. Zool. (London) 216 41-43.

WHITT GS (1970) Developmental genetics of the lactate dehydrogenase isozymes of fish. J. Exp. Zool. 175 1-35.

WRIGHT S (1978) Evolution and Genetics of Populations: A Treatise in Four Volumes. Volume 4: Variability Within and Among Natural Populations. Univ. of Chicago Press, Chicago. 580 pp. 